\title{
Slave-master Relationship and Post-colonial Translation and Teaching
}

\author{
Biook Behnam \\ Department of English, Tabriz Branch, Islamic Azad University, Tabriz, Iran \\ Farhad Azimi \\ Department of English, Tabriz Branch, Islamic Azad University, Tabriz, Iran \\ Alireza Baghban Kanani \\ Department of English, Daneshvaran Institute of Higher Education, Tabriz, Iran
}

\begin{abstract}
Two hundred years after Hegel, his Master-Slave Dialectic theory is still one of the most controversial philosophical theories. Some believe that such a relationship does no longer exist, nor is it acceptable in the face of abolishment of slavery in the world. In this study, it has been tried to form an understanding of the Hegelian Master-Slave Dialectic and bring into light the presence of the Master-Slave relationship in our modern day world. As Crossley (1996) points out, the power relation in Hegelian dialectic philosophy is ever-present in a more subtle manner in the Post-colonial era; one which utilizes an intersubjective relationship, sustaining the other as a subject of action rather than attempting to negate them (p. 147). To establish this kind of power relation, the west has been employing language, literature and translation in a much more effective way than military might to assert her control and dominance, and move the wheels of colonization and an asymmetrical power relation forward.
\end{abstract}

Index Terms-Master-Slave Dialectic, Post-Colonialism, asymmetrical power relation, Orientalism, translation, teaching

\section{INTRODUCTION}

Throughout the history of mankind, there has always been an individual or a group of individuals who has/have deemed himself/themselves to be superior and better than the others. This sense of superiority has either been originated from their inherited social stature, wealth or knowledge and race. Such feeling of superiority has created an ongoing battle for recognition and freedom from the bounds of classification and slave/master relationship. Even though at times a slave has been able to be free of such bounds but this breakage has not been absolute. The prime example of this could be the story of Spartacus who was a gladiator in Roman time. Spartacus lived in an era in which a gladiator (slave) could only gain freedom by defeating the other gladiators in a fight to death. It was then that he could gain recognition as a citizen or a free man. However, this newly found freedom never placed the victorious gladiator in the same rank as those who claimed superiority over the others. The freed gladiator was still a subordinate to his previous master.

Though the external form of the traditional slave/master relationship has changed in the post-colonial era, nevertheless it still exists in a metamorphosed shape and form. Two important question may strike one here, being in what shape and form has the slave/master relationship by Hegel manifested itself in the post-colonial era and what tools has it been employing?

In this paper we will try to take a look at the slave/master dialectic relationship as argued by Hegel and use a dangerous trend in Western style of translation and language teaching which has been dominant in the post-colonial era and persist in the present day world. Before getting to the crux of the matter, a few terms should be demystified.

\section{LITERATURE REVIEW}

\section{A. Recognition, Consciousness \& Desire for Recognition}

Recognition is one of the key terms in Hegelian philosophy. It is not automatically granted, according to Crossley (1996), to an individual. The desire for recognition is expressed in the first instance in a "fight to the death". Hegel's explanation of this fight is obscure. It involves three central claims. Firstly, in order to be human and to be recognized as such, one must place and be seen to place one's human desire above all animal desires, particularly the animal desire for self-preservation. Secondly, this implies that one must risk one's life for one's humanity. Thirdly, this is expressed in a contest in which each risks his or her life and this is a fight to death. One proves one's self in the fight to the death (Crossly, 1996, pp. 17, 18).

\section{B. Confrontation, Domination, Submission}


In Hegel's discussion of slave-master dialectic, what happens is that when two self-consciousnesses confront one another, each thinks about the other in terms of the self. The two self-consciousnesses are like mirrors of one another. Each mirror reflects the other; but it also reflects the other reflecting itself; it reflects the other reflecting itself reflecting the other. This creates two possible ending to this dilemma. One possible ending to this fight, in Hegel's view, involves one contestant killing the other (Crossley, 1996, p. 18). The problem is that if one self-consciousness kills the other, the dead self-consciousness can't do anything at all, so it can't do anything for the other. In order to be for another, selfconsciousness has to be somewhat for self (emphasis ours). If the one kills the other, it thereby destroys its own freedom, since there's nobody there to recognize its triumphant victory. You can't rule corpses: a dead servant does not obey anybody and so is free. Simply killing the other in the life-or-death combat is an "abstract negation"; it is "not the negation coming from consciousness, which supersedes in such a way as to preserve and maintain what is superseded, and consequently survives its own supersession." It's like playing a game of chicken: both contestants know that one of them has to surrender or they'll both die. The pressure on each to surrender increases (Steinhart, 1998, pp. 1-4).

\section{The Symmetry of Equality}

Steinhart (1998) points out that not surrendering is like not existing, because if nobody ever acknowledged your existence, you wouldn't exist as a person. You'd just be a personless body. Hegel puts it like this: "Self-consciousness exists in and for itself when ... it so exists for another; that is, it exists only in being acknowledged." Suppose nobody else ever talked to you or interacted with you, refused to eat with you, never touch anything you've touched, never handed you anything, how would you feel. It would be like being there and not really being there at all, it is the cruelest form of not existing but breathing. Shunning is far crueler and more effective as a threat than jail or even a beating, and it is a practice which has been around since the ancient times. Put two self-consciousnesses face-to-face and it's like putting two mirrors face-to-face: each reflects itself in the other; each sees itself in the other. At first the encounter between the two self-consciousness is perfectly symmetrical: the self-consciousnesses are so far exactly identical, so they can't distinguish themselves from one another. Am I you? Are you me? So far, there's nothing to differentiate us. We're totally alike. So we're not different persons; the symmetry destroys our personal identities. This is torture: each wants to be its own person, and so wants to end the symmetry by establishing an asymmetric relation. Each wants to dominate the other ("supersede this otherness of itself"). The tension builds (Steinhart, 1998, pp. 1-4).

\section{Master and Slave}

According to Crossly (1996), in Hegel's discussion of master-slave dialectic a fable is introduced. In this fable, two consciousnesses engage in a fight to the death, the aim of each being to achieve self-consciousness. One capitulates and thereby becomes the slave for the other, but this denies both recognition and neither becomes self-conscious. When this happens, neither the slave gets recognized, because he is the slave, and nor does the master, because the slave is not worthy of recognizing him. As he puts it, history of mankind is littered with such fights to death, some of which have resulted in the death, whilst others, as in the fable, have resulted in slavery or some equivalent form of violent domination or exclusion. He goes on to use the legacy of European colonialism, of the Soviet gulags or of the Nazi concentration camps as examples of manifestation of the violent outcome of master-slave dialectic (Crossley, 1996, pp. 146, 147).

\section{E. Literature, Master-slave Dialectic, Post-colonialism, Submission}

One may think that with the abolishment of slavery in the 20th century, such a dialectic master-slave relationship does not exist in our world, but we beg to differ. Literature is an important means at the masters' (westerners') disposal. Using literature and translation of the literary works of the east, the westerners have tried to gain dominance over the minds of the Easterners, thus keeping the more dangerous form of the master-slave relationship going. Few literary works of the east, even the masterpieces, find recognition and gain global acceptance unless they conform to the western's values for their standards of success, for the west sees the east and anything associated with it as exotic yet inferior, even its literary works (Hamadi, 2014, pp. 41, 43). Edward Said calls this Orientalism. According to Said (1977), Orientalism is the discourse of the west about the East, a huge body of text-literary, topographical, anthropological, historical and sociological-that has been accumulating since the renaissance (Said, 1977, pp. 2-5). He is concerned with showing how this discourse plays out, at once self-validating, constructing certain stereotypes which become accepted as self-evident fact, and also in conscious or unconscious collusion with political and economic Imperialism (Master-slave dialectic relationship). He believes that Orientalism is a Western style for dominating, restructuring and having authority over the orient - through reception of easterners' literary works, for example (Lodge, 1988, p. 271). Orientalism impressively combines political passion with wide-ranging scholarship. In other words, Orientalism is master-slave dialectic incognito.

\section{F. Translation, Master-slave Dialectic, Post-colonialism, Submission}

Literature is not the only means at the disposal of the modern day colonizers to create power imbalance and subjugate the colonized. To establish such an asymmetrical power relation, as Munday (2009) puts it, translation and translators also play a crucial role (p.196). Moreover, throughout the history, translation has been employed as a mighty tool for colonization and depriving the colonized from having a voice of their own. In this form of colonization, one of the 
cultures plays the role of the superior culture and gains control over the subservient culture, the culture of the colonized. In such a situation, translation shifts the scale of power in favor of the colonizer (Bassnett \& Bush, 2006, pp. 4, 329).

Spivak (1993/2004) also points out to the issue of power and colonization. She argues that, in order to exert power and colonize others, those in power use language and. "The linking of colonization and translation is accompanied by the argument that translation has played an active role in the colonization process and dissemination of an ideologically motivated image of colonized people" translation (Spivak, 1993/2004, p. 379; in Munday, 2008, p. 132). The imposing effect of ideology on translation of various literary and religious texts can be seen throughout the history. For example, in the early fifteen century the protestant reformation of Northern Europe, which was to lead to a huge schism within Christianity, began to challenge Latin through the translation of the Bible into vernacular language. In such circumstances, the translation of any book which deviated from the churches interpretation faced the risk of being considered heretical. This consideration led to such interpretation being censured or banned. In worst case scenarios, even the near act of translation could be deemed to be a threat to the established order; for example, the 1551 index of the Spanish inquisition prohibited the publication of the Bible in any vernacular language. Furthermore, what became of those who committed such acts is even more horrifying. In other words, those who undertook the act of translating the Bible into vernacular language suffered horrifying consequences and were punished severely by the church. The most well-known examples are the English theologian-translator William Tyndale (1490-1536) and the French humanist Etienne Dolet (1509-1546). Tyndale, as Munday (2008) reports, was an able linguist believed to have mastered 10 languages including Hebrew. His amazing English Bible was used to produce the Geneva Bible (1560) and King James Version (1611). King Hennery VIII ordered confiscation of any copies of Tyndale's English Bible and banned them. Then Tyndale was abducted, tried for heresy and executed in the Netherland in 1536. Etienne Dolet's sad predicament is a more prime example of ideology vs. translation. Dolet was condemned by the theological faculty of Sorbonne in 1545 . He was apparently condemned for adding the phrase rein du tout (nothing at all) in a passage about what existed after the death. The passage was translation of one of Plato's dialogues (original emphasis). For these three words he was charged with blasphemy. They accused him of not believing in life after death (immortality). For such a translation error he was burned at the stake. As these two examples show, ideology of the people in power plays a great role in acceptability and credibility of any piece of translation, especially translation of the religious texts. Considering these two examples, Bassnett and Trivedy's statements about the role of translation in producing ideological images from various concepts being a shameful act, gains credibility (Munday, 2008, pp. 23, 132).

In the same vein, Lefevere (1992) places the emphasis mainly on the factors which are concrete rather than abstract. These factors, according to him, dominate and control the process by which literary works are received, find acceptance or rejected. In other words, he focuses on issues like ideology, power and manipulation (Lefevere, 1992, pp. 2-35). He believes that people in power are the ones who decide how a piece of literary text should be rewritten and how it should be consumed by the general public. In other words, those in power play the role of the commissioner in Vermeer's Skopos Theory (Behnam, et al., 2014, pp. 714, 715). The masters decide what the slaves should read and how it should be read. The motivations of the masters/commissioners, according to Lefevere (1992), in such rewriting can be ideological or poetological. He believes that if the motive behind the rewriting is ideological, it conforms to or rebels against the dominant ideology. When the case is in position of the ideology of the masters or the colonizers, rewriting conforms to the dominant ideology being the ideology of the masters/commissioners. However, if the dominant culture is the culture of the slaves or the colonized, the rewriting of the literary text rebels against that ideology.

Edward Fitzgerald's translation of Rubayait Omar Khayyam (Persian Poet, astronomer and mathematician) is a clear role of ideology in translation. The footprint of ideology and power relations in his translation is very clear as Fitzgerald believed that Persian language is inferior to English language and felt that he should take certain liberties in the translation in order to improve on the original version of the Khayyam's Rubayait (Munday, 2008, pp. 125, 126). That is why some of the scholars such as Niranjana, Spivak, and Cheyfitz believed that during the past eras translation has been used as an effective tool in the hands of colonialists for depriving the colonized from having a voice of their own. They believe that in the colonial model one of the cultures has always been deemed superior to the other: in this relationship the superior one being the culture of the colonizer and the inferior one being the culture of the colonized (Bassnett, 1980, p. 4). Another prime example of the role of translation in postcolonial era is shown by Niranjana (1992). She argues that "the British colonial project in India was strengthened by translations inscribed with the colonizers' image of the colonized, an ethnic or racial stereotype that rationalized domination. After the introduction of English education in India, Indians came to study orientalist translations of Indian-language texts, and many acceded both to the cultural authority of those translations and to their discriminatory images of Indian cultures" (Venuti, 2000, p. 337). Moreover, a strongly ethnocentric translation practice could be used as vessel for delivering dominance. Cheyfitz (1991) also argues that such an ethnocentric translation has paved the way for the West to exercise imperialism and colonialism over the New World; Venuti (1995) calls this "domesticating translation" (Venuti, 2000, p. 329; Shuttleworth and Cowie, 1997, pp. 43, 44). In other words, domestication takes place by the translator to minimize the influence of the source text on the target text and make the target text more natural and culturally more understandable and closer to the target language readers' cultural values, norms and expectations. The goal of such undertaking is ideologically tainted. The translator, by adopting domesticating strategy, tries to downplay the influence of the foreign culture and language making it more acceptable to its target audience and placing an emphasis on the superiority of the target language and 
culture (Yang, 2010, pp. 77, 78). However, the role of translation could be reversed. It may also be used as a tool of resistance to colonial and neo-colonial powers (Baker \& Saldanha, 2009, p. 202).

\section{G. Language Teaching, Master-slave Dialectic, Post-colonialism, Submission}

This power relation and language, in general, as a tool in the hands of the colonizers is not limited and does not stop with literature and translation. Spivak (1993/2000) asserts that "if you are interested in talking about the other, and in making a claim to be the other, it is crucial to learn other languages (Spivak, 1993/2000, p. 190; as cited in Hatim and Munday, 2004, pp.317, 338). It is also, according to the scholars who oppose methods in English teaching, evident in the methodologies offered in second language and foreign language teaching. Kumaravadivelu (2006) identifies four interrelated dimensions to method as a means of marginality namely, linguistic, cultural, scholastic and economic. These four dimensions of method as a means of marginality tend to extend and expand the agenda for sustaining "an ideological dependence." Another parameter which Kumaravadivelu introduces is the parameter of possibility. He gives the credit for this parameter coming into light to the Brazilian philosopher, Paulo Freire. He and his followers, Giroux and Simon, believed that any pedagogy is closely related to dominance and power. Furthermore, its goal is to establish and maintain social inequalities. They place emphasis on the vitality and importance of acknowledging teachers' and students' individual identity. Moreover, they point out that these teachers and students should question the status quo which holds them subjugated and oppressed (Kumaravadivelu, 2006, p. 174).

Looking at language teaching from this perspective makes it possible to look at the methods in teaching English as a tool for subjugation and oppression. That's why in the post-method era educators have mostly done away with the methods and replaced it with the concept of learner's autonomy and glocalization. Glocalization is, in essence, the result of learner's autonomy and resistance to globalization and the use of Standard English as a tool in the hands of Imperialism. It takes into account the experiences of the learners which they bring into a pedagogic setting. It also incorporates the teacher's personal and professional experiences, too. Ganagarajah (1999) reported on how Tamil students of English in the civil war -torn Sri Lanka offered resistance to western representations of English language and culture and how they, motivated by their own culture and historical backgrounds, appropriated the language and used it in their own terms according to their own aspirations, needs, and values. He reported how the students, through marginal comments and graphics, actually refrained, reinterpreted and rewrote the content of their ESL textbooks written and produced by Anglo Saxon authors (Kumaravadivelu, 2006, p.174, 175).

Communicative Language teaching is a perfect example of the standardized methods of teaching which has faced difficulties in its implementation in various countries. Chick (1996) argued whether "our choice of communicative language teaching as a goal was possibly a sort of naïve ethnocentrisms promoted by the thought that what is good for Europe or the USA had to be good for KwaZulu" Pakir (1999) suggested that communicative language teaching with its professional practices based on Anglo-Saxon assumptions has to be modified taking into account what she called "glocal" linguistic and cultural considerations. Tickoo (1996) narrated how even locally initiated, pedagogic innovations have failed because the merely tinkered with the method-based framework inherited from abroad. (Kumaravadivelu, 2006, pp.171, 172).

Another great example of the resistance shown by the people whose mother tongues is not English is provided by Xing Fang (2011). He points out that the initial spread of English language started with American and British colonialism and migration of English-speaking individuals to other parts of the world during the eighteen and the nineteen centuries. Moreover, the spread of English became much more widespread as the result of English language becoming the Lingua Franca. This brought about the phenomenon of marginalization of the indigenous languages. Scholars such as Philipson (1992) doesn't see this event as an accidental happening. He argues that "the global spread of English is a matter of deliberate policy on the part of core English-speaking countries to maintain dominance over periphery countries, in many cases, developing countries. Also, he introduces the term linguistic imperialism and considers it as a type of cultural imperialism by claiming that the dominance of English is asserted and maintained by the establishment and continuous reconstitution of structural and cultural inequalities between English and other languages". As indigenized Englishes in Outer Circle countries are gradually claiming their legitimate status, it is only appropriate and needed for the Chinese people to launch a revolution of English use in order to offset the negative effects that the powerful global language is inflicting upon local indigenous languages (emphasis ours) (Fang, 2011, p.377, 378). As the result of the resistance of the speakers of English as a second language to losing their identity and culture and having it replaced with the core-English speaking countries' culture, varieties of English have been developing around the globe. Singapore and Hindi English are two prime examples of such varieties in which the people who speak them change the Standard English and make it fit their own identities, cultures, norms and needs.

\section{MEthodology}

There was no data and interventions in this research to make it a quantitative or even a semi-quantitative research. Thus, only qualitative methods were used in the course of this research. Library research and an extensive review of the literature were used to support the points the researchers were trying to make.

\section{RESUlt, DisCUSSION \& CONCLUSION}


Hegelian master-slave dialectic has been the Mecca of the philosophers who deal with the sociocultural and intersubjective aspects of the mankind's social behavior. Individuals' interrelations with one another, self-perceptions and many other issues can be explained using this theory. Some believe that such a relationship does not exist in today's world, and Hegelian dialectic master-slave relationship isn't present nowadays, but we are of firm belief that, though the external form of the traditional slave/master relationship has changed in the post-colonial era, nevertheless it still exists in a metamorphosed shape and form. The masters have been using literature, translation and teaching methodologies to establish their own superiority over their slaves in a much more dangerous way than before. Slavery of the minds has been their new motive. Orientalism, as Said (1988) argues, is a perfect example of such efforts. This new form employs language, in general, and literature, translation and teaching methods, in particular, as mighty tools for colonizing. Being aware of the subtle and deceitful ways of the modern colonizers-masters, will enable us to take certain measures to neutralize their subjugation efforts and slavery of the minds of the colonized, third world countries' people.

\section{REFERENCES}

[1] Baker, M \& Saldanha, G. (2009). Routledge Encyclopedia of Translation Studies. Abingdon: Rourledge.

[2] Bassnett, S. (1980). Translation Studies. New York: Routledge.

[3] Bassnett, S. \& Bush, P. (2006). The Translator as Writer. London \& New York: Bloomsbury Academic.

[4] Behnam, B. \& Azimi, F. \& Hajarizadeh, P. (2014). Machine Translation and Skopos Theory: Post-modernist Approach to Interlingual Translation. Journal of Language Teaching and Research, 5(3): 714-721.

[5] Crossley, N. (1996). Intersubjectivity. London: SAGE Publication.

[6] Fang, X. (2011). Glocalizing ELT: From Chinglish to China English. Journal of Language Teaching and Research, 2(2): $377-$ 381.

[7] Hamadi, L. (2014). Edward Said: The Postclonial Theory \& The Liturature of Decolonization. European Scientific Journal, 2: $39-46$.

[8] Hatim, B. \& Munday, J. (2004). Translation: An Advanced Resource Book. Oxon: Routledge.

[9] Kumaravadivelu, B. (2006). Understanding Language Teaching: From Method to Postmethod. Mahwah: Lawrence Erlbaum Associates.

[10] Lefevere, A. (1992). Translation, Rewriting and Manipulation of Literary Fame. London \& New York: Routledge.

[11] Lodge, D. (1988). Modern Criticism and Theory. Essex: Pearson Education Limited.

[12] Munday, J. (2008). Introducing Translation Studies: Theories \& Applications. Oxon: Routledge.

[13] Munday, J. (2009). The Routledge Companion to Translation Studies. Oxon: Routledge.

[14] Said, E. W. (1977). Orientalism. London: Penguin.

[15] Shuttleworth, M. \& Cowie, M. (1997). Dictionary of Translation Studies. Manchester: St. Jerome.

[16] Steinhart, E. (2014, March 15). The Master// Slave Dialectic. Avalable in www.ericsteinhart.com/progress/HEGEL/MASLAVE.HTM. Retrived in: March 15, 2014

[17] Venuti, L. (2000). The Translation Studies Readers (2nd ed.). New York: Routledge.

[18] Yang, W. (2010). Brief Study on Domestication \& Foreignization in Translation. Journal of Language Teaching and Research, 1(1): 77-80.

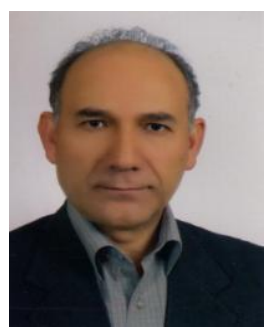

Biook Behnam is an Associate Professor of Applied Linguistics at Islamic Azad University, Tabriz branch, Iran. His current research interests cover Discourse Analysis, ELT and Translation Studies. He has been involved in a wide range of projects in the area of Applied Linguistics and Discourse Analysis as a project director, consultant and researcher. He has widely presented papers to national and international conferences in North America, Australia, Europe, China, India and South East Asia. He is currently the Editor-in-Chief of the Journal of Applied Linguistics published by IAU, Tabriz Branch.

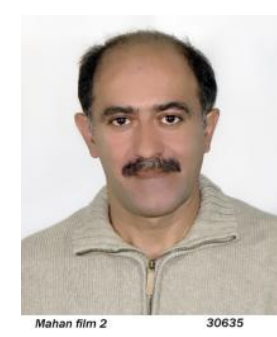

Farhad Azimi was born in 1964, in Tabriz. He finished high school in Tabriz and moved to the U.S. to continue his education. He has an MA degree in translation studies. Currently, he is serving as the literary editor for two well-known journals in the field of architectural engineering \& urban planning. He also has been teaching at the PNU in Qazvin and Meshkin Shahr since 2010 and in Islamic Azad University since 2013. He has translated over a dozen documentaries for the use in national TV. He, currently, is working on his PhD in TEFL at the Islamic Azad University of Tabriz, Iran. 


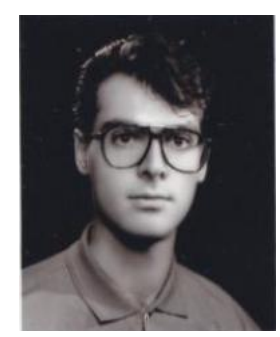

Alireza Baghban Kanani was born in Tabriz, Iran on September 22, 1971. He holds an M.A. in Translation Studies from Alborz Institute of Higher Education, Gazvin, Iran. He lives in Tabriz and received his B.A. in the field from Azad University of Tabriz, Iran in 2008. He presently teaches Translation Studies and general English in Daneshvaran Institute of Higher Education and Nabi Akram Institute of Higher Education in his hometown. Besides teaching various courses on Translation Studies and general English, he does some practical translational affairs from English to Persian- two books on psychology to be more precise. His main areas of interest include Translation Studies, Critical Discourse Analysis, Political Discourse, News Analysis and Media Representation. 